DOI: https://doi.org/10.31933/dijms.v2i2 Received: 11August 2020, Revised: 15 October 2020, Publish: 27 November 2020

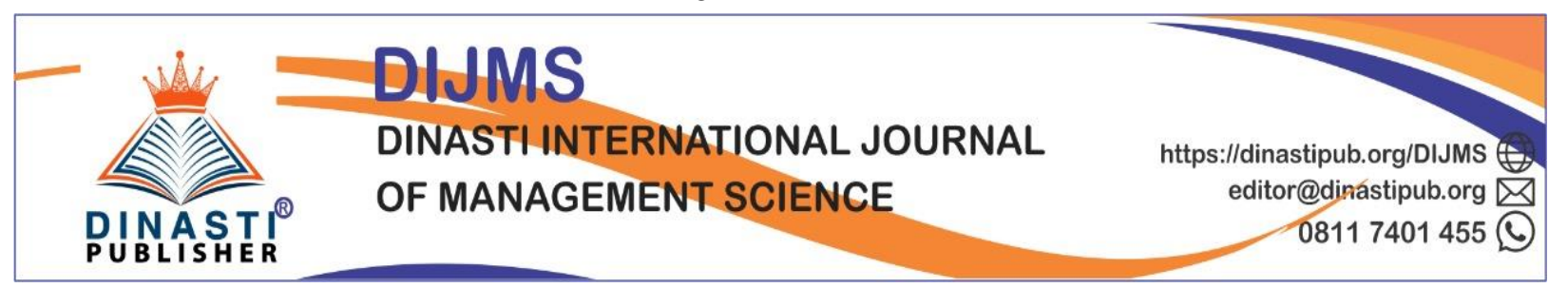

\title{
THE EFFECT OF JOB SATISFACTION, ORGANIZATIONAL COMMITMENT, AND LEADERSHIP ON ORGANIZATIONAL CITIZENSHIP BEHAVIOR EMPLOYEES OF BRI IN YOGYAKARTA
}

\author{
Aulia Syaflinursyah ${ }^{1}$, Nur Aktif ${ }^{2}$ \\ ${ }^{1)}$ Magister Manajemen, Mercubuana University, Jakarta, Indonesia, auliasyaflinursyah@ gmail.com \\ ${ }^{2)}$ Magister Manajemen, Mercubuana University, Jakarta, Indonesia, nuraktif123@gmail.com
}

Corresponding Author: Aulia Syaflinursyah

\begin{abstract}
Organizational citizenship behavior is important for the success of an organization because basically organizations cannot directly anticipate and improve all behavior in organizations simply by relying on formally instructed job descriptions. This study aims to examine and analyze the effect of job satisfaction, organizational commitment, and leadership on organizational citizenship behavior of BRI employees in Yogyakarta. The study used a quantitative approach with multiple linear regression quantitative analysis methods using SPSS 25.0. The number of samples taken in this study was 83 respondents using the saturated sampling method. Research result shows that (1) there is an effect of job satisfaction on organizational citizenship behavior, (2) there is an effect of organizational commitment on organizational citizenship behavior, (3) there is an effect of leadership on organizational citizenship behavior, (4) there is an effect of job satisfaction, organizational commitment, and leadership on organizational citizenship behavior simultaneously.
\end{abstract}

Keywords: job satisfaction, leadership,organizational commitment,organizational citizenship behavior.

\section{INTRODUCTION}

The very rapid development of the banking industry has caused the bank's business competition to become very sharp, so that efforts to win the competition are implemented, among others, by providing service excellence so as to create customer satisfaction and loyalty. The bank is an intermediary organization that provides financial services to collect and channel public funds with the aim of improving people's lives and quality of service is one of the most important factors affecting customer satisfaction. This is because customers expect to get the best service. Therefore, banks strive to provide excellent service so that customers continue to use bank services in fulfilling their financial transactions.

The bank is an organization that has a goal or vision by carrying out the mission that has been made, to improve and advance the organization. In realizing this vision, a bank needs 
human resources, because human resource is one of the assets owned by the bank as a driver, guide and developer of the organization.

Bank employees in an organization must have different individual potentials and needs which will result in different desires, mindsets, behavior and work motivation. The level of satisfaction with the job and the tasks they have is also different, there are those who feel they have to do other things that are not their main job, but some are only satisfied with their work.

BRI Yogyakarta Cik Ditiro Branch Office as one of the branch offices of the BRI Yogyakarta Region is a bank branch that continues to grow and enter increasingly competitive conditions. Currently, the main target of BRI Yogyakarta Cik Ditiro is to be included in the list of Top Five Branches in the BRI Yogyakarta Region. One way to achieve this goal is to be able to manage human resources properly, such as raising organizational citizenship behavior (OCB) to every employee.

The pre-survey results obtained show that job satisfaction, organizational commitment, and leadership are the three factors that cause Organizational Citizenship Behavior (OCB) ofall employees, then, the researcher focused on the effect of job satisfaction, organizational commitment, and leadership on Organizational Citizenship Behavior (OCB) BRIYogyakarta employees of Cik Ditirobranch office.

The purpose of this study was to determine and analyze (1) the effect of job satisfaction on Organizational Citizenship Behavior (OCB) employees of BRI Yogyakarta Cik Ditiro branch office, (2) the effect of organizational commitment on Organizational Citizenship Behavior (OCB) employees of BRIYogyakarta Cik Ditiro branch office, (3) the effect of leadership on Organizational Citizenship Behavior (OCB) employees of BRIYogyakarta Cik Ditiro branch office, (4) the effect of job satisfaction, organizational commitment, and leadership simultaneously on Organizational Citizenship Behavior (OCB) employees of BRIYogyakarta Cik Ditiro branch office.

\section{LITERATURE REVIEW}

\section{Organizational Citizenship Behavior (OCB)}

Budiharjo (2014) defines OCB as optional behavior that does not become part of an employee's formal work obligations, but supports the effective functioning of the organization. Robin and Judge (in Ristiana, 2013) explained thatOCB is the voluntary behavior of an employee to want to do an extra task or job more than his/her responsibility or obligation for the advancement or benefit of the organization.

Meanwhile, according to Garray (in Waspodo, 2012), OCB is a form of behavior which is an individual choice and initiative, not related to the rewardsystem.Garray (in Waspodo, 2012) explains thatOCB is the behavior of employees who practice additional roles and show their contribution to the organization beyond their specific roles in work, willingness and participation to do business that exceeds formal responsibilities in the organization is something that is effective in improving the functioning of an organization.

Organ (2006) confirmed that OCB is an individual behavior that is discretionary, which is not directly and explicitly rewarded by the formal reward system, and as a whole encourages the effectiveness of organizational functions. Furthermore, Organ (in Herminingsih, 2012) 
stated that behavior of citizenship or extra roles is implemented in 5 forms of behavior, namely: (1) alturism; is the behavior of employees in terms of providing help to colleagues who have difficulty working, (2) courtesy; is a form of action or behavior that aims to prevent problems, (3) sportsmanship; can be seen from the aspects of tolerance and individual complaints at work, (4) proactive (civic virtue); is behavior that indicates responsibilityon organizational life.

\section{Job satisfaction}

Job satisfaction is an expression of employee satisfaction about how their work can provide benefits to the organization, which means that what is gained in work fulfills what is considered important (Luthans 2006).

According to Robbins (in Ningsih, 2014), job satisfaction is a general individual feeling that is associated with work. Positive or negative feelings about work are the result of an internal evaluation process within a person.

As'ad (2004) stated that there are nine factors for job satisfaction of employees, namely; (1) supervision; is a supervisory style, either task-oriented or person-oriented, (2) colleagues; consisting of teaching, work groups and social aspects in officesetting, coworkers, family members, and neighbors that can affect individual job satisfaction, (3) work conditions; are the physical conditions of the work environment, (4) rewards (pay); namely annual income that can serve as an indicator and influence on achievement or failure, (5) responsibility; is the desire to be responsible for work to help colleagues and the opportunity to participate in strategic activities, (6) the work itself; namely work or tasks related to work, (7) promotion (advancement); namely changes in status or position, including an increase in opinion. Promotion has an important contribution in meeting the psychological needs of anemployee, (8)job security; organizational policies regarding levels of office, seniority, dismissal and retirement, and (9) awards (recogniton), namely attention, appreciation, prestige and all forms of appreciation from supervisors, colleagues, and superiors.

\section{Organizational Commitment}

Darmawati (2013) states that organizational commitment is a condition of an employee who sides with the organization where he works, as well as his goals and desires to maintain membership in the organization. The commitment of the individual is indicated by the action, for example, individuals with high commitment will remain in the organization and will have a positive view of the organization. In addition, individuals will show consistent behavior to keep a positive self-perception.

Luthans (2006) views organizational commitment as an attitude that has a wide variety of definitions and measurements. Commitment is defined as (1) a strong desire to remain as a member of a particular organization, (2) the desire to strive for the organization's wishes, and (3) certain beliefs and acceptance of the organization's values and goals. In other words, organizational commitment is an attitude that reflects employee loyalty to the organization and a continuous process in which organizational members express their concern for the organization and its success and continuous progress.

Furthermore, Luthans (2006) said that as attitude, organizational commitment is most often defined as follows: (1) a strong desire to remain as a member of a particular organization; 
(2) the desire to try hard according to the wishes of the organization; (3) certain beliefsand acceptance of the organization's values and goals. In other words, this is an attitude that reflects employee's loyalty to the organization and a continuous process in which organizational members express their concern for the organization and its continued success and progress.

According to Meyer and Allen (2013), there are three components in organizational commitment, namely (1) affective commitment; related to emotional attachment, organizational identification, and employee's involvement in the organization, (2) continuous commitment; related to an awareness of the costs associated with leaving the organization.

This shows that there is a benefit and loss consideration in employees related to the desire to keep working or leave the organization. Continuous commitment is awareness of the impossibility of choosing another social identity or other alternative behavior because of the threat of large losses, (3) normative commitment; reflecting a feeling of obligation to continue employment. In other words, normative commitment is related to the feeling of being obliged to continue working in the organization.

\section{Leadership}

Leadership is the ability to influence a group to achieve a series of goals (Robbins et al, 2008). Whereas Griffin (2012) defines leadership as a process, leadership is a good use of influence to direct and coordinate the activities of members to achieve goals. As a trait, leadership is a set of characteristics attributable to who has the right to exercise influence successfully.

Avolio et al, (2003) suggested four characteristics of transformational leadership, namely; (1) idealized influence, a leader must be a good example, which can be followed by employees so as to generate respect and trust in the leader, (2)inspirational motivation, the leader must be able to provide clear motivation and achievement targets, (3) intellectual simulation, the leader must be able to motivate his employees to come up with innovative ideas and ideas, and (4) individualized consideration, the leader must be able to pay attention, listen to complaints, and understand the needs of employees.

\section{RESEARCH METHODS}

This research data collection method is a cross-sectional survey which is also a descriptive research method where the information collected is carried out only at a certain time.

Based on its objectives, this study is an explanatory study that aims to explain the causal relationship (influence) and test the hypothesis. This study aims to determine the effect of job satisfaction, organizational commitment, and leadership on organization citizenship behavior (OCB) employees of BRI Yogyakarta CikDitiro branch office. The population in this study were 108 employees of BRI Yogyakarta CikDitiro branch office with a sample size of 83 respondents.

\section{FINDINGS AND DISCUSSION}

Validity test 
The validity test is carried out using Pearson Product Moment correlation, if $\mathrm{r}$ count $>$ $\mathrm{r}$ table, it means valid. If $\mathrm{r}$ count $>\mathrm{r}$ table with $\mathrm{df}=\mathrm{n}-2(81)$ the value is 0.2146 with $\alpha=0.05$, then the correlation coefficient is significant.

The following table shows the results of the validity test on job satisfaction (X1), organizational commitment (X2), leadership (X3), and variables OCB (Y) for each indicator.

Table 1. Validity Test ResultsofJob Satisfaction Variable (X1)

\begin{tabular}{cccc}
\hline Indicator Codes & r Count & Terms & Information \\
\hline KK1 & 0.701 & $>0.2146$ & Valid \\
\hline KK2 & 0.685 & $>0.2146$ & Valid \\
\hline KK3 & 0.728 & $>0.2146$ & Valid \\
\hline KK4 & 0.676 & $>0.2146$ & Valid \\
\hline KK5 & 0.733 & $>0.2146$ & Valid \\
\hline KK6 & 0.700 & $>0.2146$ & Valid \\
\hline KK7 & 0.667 & $>0.2146$ & Valid \\
\hline KK8 & 0.741 & $>0.2146$ & Valid \\
\hline KK9 & 0.703 & $>0.2146$ & Valid \\
\hline KK10 & 0.683 & $>0.2146$ & Valid \\
\hline KK11 & 0.710 & $>0.2146$ & Valid \\
\hline KK12 & 0.577 & $>0.2146$ & Valid \\
\hline KK13 & 0.619 & $>0.2146$ & Valid \\
\hline KK14 & 0.595 & $>0.2146$ & Valid
\end{tabular}

**. Correlation is significant at the 0.01 level (2-tailed).

Source: Results of analysis of SPSS 25.0

Based on table 1, the results of validity test can be seen that the job satisfaction variable (X1) which consists of 15 question items, has a calculated that $r$ value $>r$ table $=0.2146$. Therefore, the job satisfaction variable (X1), which consists of 15 indicators of question items, is declared valid.

Table 2. Validity Test Results of Organizational Commitment Variable (X2)

\begin{tabular}{cccc}
\hline Indicator Codes & r Count & Terms & Information \\
\hline KO1 & 0.644 & $>0.2146$ & Valid \\
\hline KO2 & 0.688 & $>0.2146$ & Valid \\
\hline KO3 & 0.653 & $>0.2146$ & Valid \\
\hline KO4 & 0750 & $>0.2146$ & Valid \\
\hline KO5 & 0.825 & $>0.2146$ & Valid \\
\hline KO6 & 0.643 & $>0.2146$ & Valid \\
\hline KO7 & 0.789 & $>0.2146$ & Valid \\
\hline KO9 & 0835 & $>0.2146$ & Valid \\
\hline KO10 & 0.725 & $>0.2146$ & Valid \\
\hline KO11 & 0800 & $>0.2146$ & Valid \\
\hline KO12 & 0844 & $>0.2146$ & Valid \\
\hline KO13 & 0.839 & $>0.2146$ & Valid \\
\hline KO14 & 0.721 & $>0.2146$ & Valid \\
\hline KO15 & 0.639 & $>0.2146$ & Valid
\end{tabular}

Source: Results of analysis of SPSS 25.0 
Based on table 2, the results of validity test can be seen that the organizational commitment variable (X2) which consists of 15 question items, has a calculated that $r$ value > $\mathrm{r}$ table $=0.2146$. Therefore, the organizational commitment variable (X2), which consists of 15 indicators of question items, is declared valid.

Table 3. IndicatorValidity Test ResultsofLeadership Variable (X3)

\begin{tabular}{|c|c|c|c|}
\hline Indicator Codes & r Count & Terms & Information \\
\hline $\mathrm{K} 1$ & 0.463 & $>0.2146$ & Valid \\
\hline $\mathrm{K} 2$ & 0.602 & $>0.2146$ & Valid \\
\hline $\mathrm{K} 3$ & 0.603 & $>0.2146$ & Valid \\
\hline K4 & 0.649 & $>0.2146$ & Valid \\
\hline K5 & 0.536 & $>0.2146$ & Valid \\
\hline K6 & 0.617 & $>0.2146$ & Valid \\
\hline K7 & 0.414 & $>0.2146$ & Valid \\
\hline K8 & 0.417 & $>0.2146$ & Valid \\
\hline K9 & 0.499 & $>0.2146$ & Valid \\
\hline K10 & 0.606 & $>0.2146$ & Valid \\
\hline K11 & 0.523 & $>0.2146$ & Valid \\
\hline K12 & 0.466 & $>0.2146$ & Valid \\
\hline K13 & 0.455 & $>0.2146$ & Valid \\
\hline K14 & 0.546 & $>0.2146$ & Valid \\
\hline K15 & 0.342 & $>0.2146$ & Valid \\
\hline
\end{tabular}

Source: Results of analysis of SPSS 25.0

Based on table 3, the results of validity test can be seen that the leadership variable (X3) which consists of 15 question items, has a calculated $r$ value $>r$ table $=0.2146$. Therefore, the leadership variable (X3), which consists of 15 question indicator items, is declared valid.

Table 4. IndicatorValidity Test ResultsofVariable OCB (Y)

\begin{tabular}{cccc}
\hline Indicator Codes & r Count & Terms & Information \\
\hline OCB1 & 0.326 & $>0.2146$ & Valid \\
\hline OCB2 & 0.533 & $>0.2146$ & Valid \\
\hline OCB3 & 0.448 & $>0.2146$ & Valid \\
\hline OCB4 & 0.491 & $>0.2146$ & Valid \\
\hline
\end{tabular}




\begin{tabular}{cccc}
\hline OCB5 & 0.514 & $>0.2146$ & Valid \\
\hline OCB6 & 0.480 & $>0.2146$ & Valid \\
\hline OCB7 & 0.503 & $>0.2146$ & Valid \\
\hline OCB8 & 0.381 & $>0.2146$ & Valid \\
\hline OCB9 & 0.422 & $>0.2146$ & Valid \\
\hline OCB10 & 0.588 & $>0.2146$ & Valid \\
\hline OCB11 & 0.444 & $>0.2146$ & Valid \\
\hline OCB12 & 0.476 & $>0.2146$ & Valid \\
\hline OCB13 & 0.552 & $>0.2146$ & Valid \\
\hline OCB14 & 0.671 & $>0.2146$ & Valid \\
\hline OCB15 & 0.453 & $>0.2146$ & Valid \\
\hline **. Correlation is significant at the 0.01 level (2-tailed).
\end{tabular}

Source: Results of analysis of SPSS 25.0

Based on table 4, the results of validity test can be seen that for the variables OCB (Y) which consists of 15 question items, has a value of $r$ count $>r$ table $=0.2146$. Therefore, variable OCB (Y) which consists of 15 items of question indicators declared valid.

\section{Reliability Test}

Reliability relates to the consistency and predictability test of a measuring instrument. The test is carried out by comparing the Cronbach Alpha numbers where the Cronbach Alpha value is at least 0.6 or $\geq 0.6$. If the value is generated from the calculation result SPSS greater than 0.6 then the questionnaire is reliable, whereas otherwise it is not reliable.

Table 5. Variable Indicator Reliability Test Results

\begin{tabular}{cccc}
\hline Variable & Cronbach's Alpha value & Terms & Information \\
\hline Job satisfaction & 0.761 & $>0.6$ & Reliable \\
\hline Organizational Commitment & 0.766 & $>0.6$ & Reliable \\
\hline Leadership & 0.733 & $>0.6$ & Reliable \\
\hline OCB & 0.723 & $>0.6$ & Reliable
\end{tabular}

Source: The results of the analysis using SPSS 25.0

Based on table 5, the reliability test results can be seen that for the variable job satisfaction (X1), organizational commitment (X2), leadership (X3), and the variable OCB (Y), has a Cronbach's Alpha value of $0.761,0.766,0.733$, and 0.723 and all the values is above 0.6. Then, the variable job satisfaction (X1), organizational commitment (X2), leadership (X3), and variablesOCB (Y), stated reliable.

\section{Normality test}




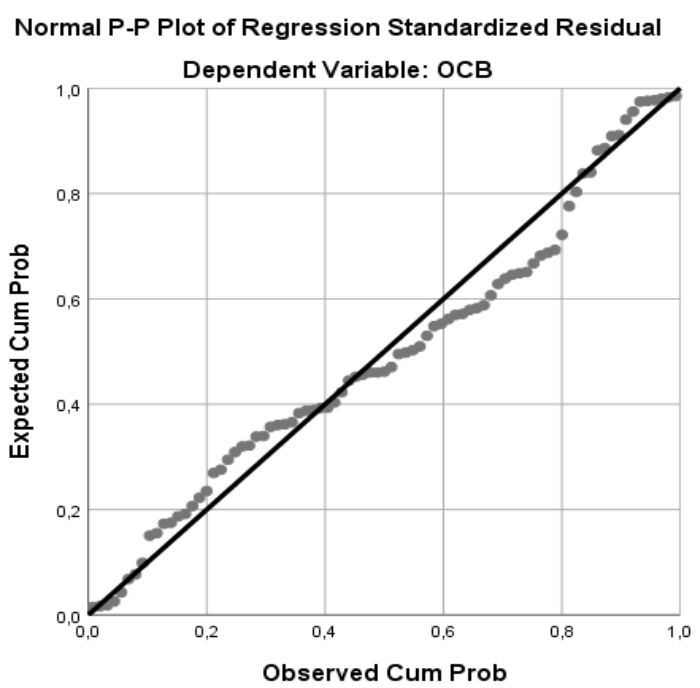

Source: Results of analysis of SPSS 25.0

Figure 1. Data Normality Test Results

Table 6. Data Normality Test Results

\begin{tabular}{|c|c|c|c|c|c|}
\hline \multicolumn{6}{|c|}{ One-Sample Kolmogorov-Smirnov Test } \\
\hline & & $\begin{array}{c}\text { Job } \\
\text { satisfaction }\end{array}$ & $\begin{array}{c}\text { Organizational } \\
\text { Commitment }\end{array}$ & Leadership & Y OCB \\
\hline \multicolumn{2}{|l|}{$\mathbf{N}$} & 83 & 83 & 83 & 83 \\
\hline \multirow{2}{*}{$\begin{array}{l}\text { Normal } \\
\text { Parametersa, } \\
\text { b }\end{array}$} & Mean & 3.16 & 3.09 & 3.01 & 3.58 \\
\hline & $\begin{array}{l}\text { Std. } \\
\text { Deviation }\end{array}$ & 0.52 & 0.53 & 0.43 & 0.27 \\
\hline \multirow{3}{*}{$\begin{array}{l}\text { Most } \\
\text { Extreme } \\
\text { Differences }\end{array}$} & Absolute & 0.090 & 0.094 & 0.068 & 0.093 \\
\hline & Positive & 0.078 & 0.083 & 0.065 & 0.093 \\
\hline & Negative & -0.090 & -0.094 & -0.068 & -0.063 \\
\hline \multicolumn{2}{|c|}{ Statistical Test } & 0.090 & 0.094 & 0.068 & 0.093 \\
\hline \multicolumn{2}{|c|}{ Asymp. Sig. (2-tailed) } &, $092^{\mathrm{c}}$ &, $066^{\mathrm{c}}$ &, $200^{\mathrm{CD}}$ &, $074^{\mathrm{c}}$ \\
\hline
\end{tabular}

a. Test distribution is Normal.

b. Calculated from data.

c. Lilliefors Significance Correction.

d. This is a lower bound of the true significance.

Source: Results of analysis of SPSS 25.0

The assumption for normality shown in Figure 1 states that data on the histogram graph follows a normal line, and the distribution of data on the normal P-Plot chart is located around the diagonal line. Meanwhile, based on table 6, the results of the Kolmogorov-Smirnov normality test show that the Sig. of the four variables more than the value of $\alpha=0.05$, and the calculated KS value $<$ table KS value $(1.35 / \sqrt{ } 83=0.148)$. Therefore, the KolomogorovSmirnov test results of the four variables above have met the normality requirements with the Sig. $>\alpha=0.05$. It can be concluded that the data being tested had a normal data distribution.

\section{Multicollinearity Test}

Table 7. Multicollinearity Test Results Data 


\begin{tabular}{|l|c|c|}
\hline \multirow{2}{*}{ Model } & \multicolumn{2}{c|}{ Coefficientsa } \\
\cline { 2 - 3 } & Tolerance & VIF \\
\hline (Constant) & & 1,236 \\
\hline Job satisfaction & 0.809 & 1,187 \\
\hline Organizational Commitment & 0842 & 1,258 \\
\hline Leadership & 0.795 & \\
\hline
\end{tabular}

a. Dependent Variable: OCB

Source: Results of analysis of SPSS 25.0

Based on table 7, the VIF value of each variable is less than 10 . This, it can be concluded that the data tested did not occur multicollinearity.

\section{Heteroscedasticity Test}

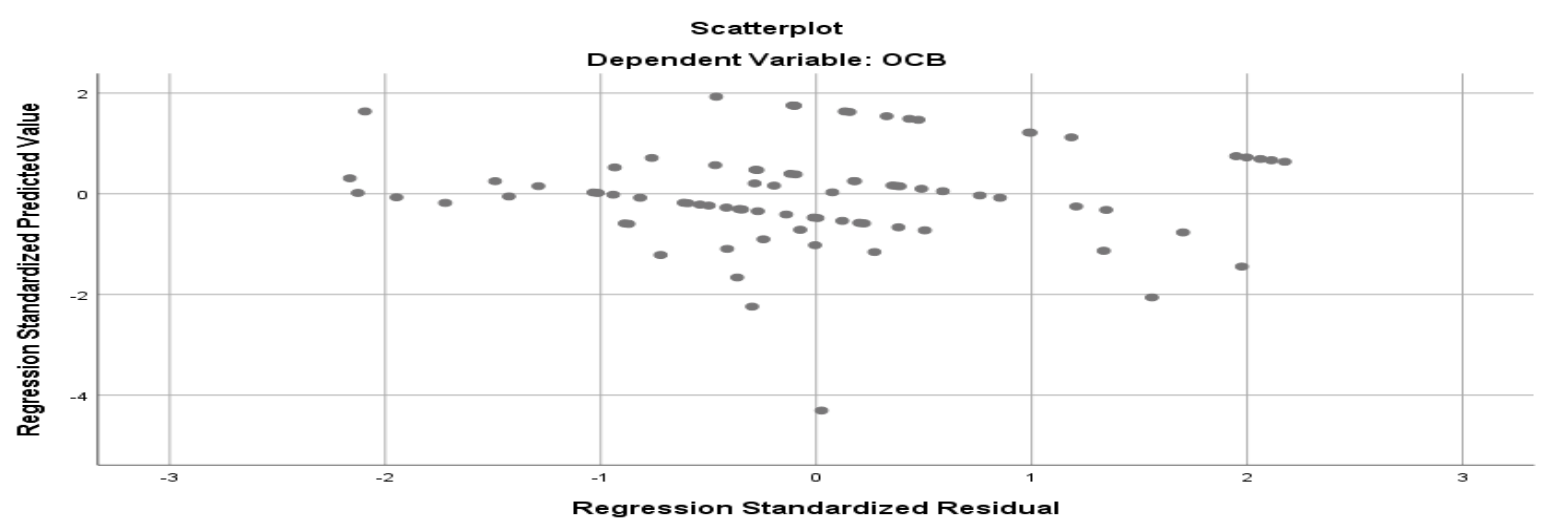

Source: Results of analysis of SPSS 25.0

\section{Figure 2. Heteroscedasticity Test Results}

Based on Figure 2, it can be seen that there is no clear pattern such as dots stretching above and below the number 0 on the $\mathrm{Y}$ axis, the dots spreading randomly, and not forming a particular pattern. It can be concluded that the data being testedfree from heteroscedasticity.

Table 8. Resultsof The F OCB Test Analysis

\begin{tabular}{l|l|r|r|r|r|r}
\hline \multicolumn{2}{c}{ Model } & Sum of Squares & \multicolumn{1}{c}{ Df } & \multicolumn{1}{c}{ Mean Square } & \multicolumn{1}{c}{ F } & \multicolumn{1}{c}{ Sig. } \\
\hline \multirow{2}{*}{ Regression } & 4,908 & 3 & 1,636 & 114,042 & $.000 \mathrm{~b}$ \\
\cline { 2 - 7 } & Residual & 1,133 & 79 & 0.014 & & \\
\cline { 2 - 7 } & Total & 6,041 & 82 & & & \\
\hline
\end{tabular}

a. Dependent Variable: OCB

b. Predictors: (Constant), Leadership, Organizational Commitment, Job Satisfaction Source: Results of analysis of SPSS 25.0

Based on table 8 above, it is known that the value of $\mathrm{F}=114.042$, and the value of Sig. $=0.000$, while the value of the F table with $\mathrm{df}(3,79)=2.72$. Therefore, H0c is rejected, it is variable job satisfaction (X1), organizational commitment (X2), and leadership (X3) simultaneously have a significant effect on variable OCB (Y).

\section{Hypothesis Test}


Table 9. Multiple Linear Regression Results of OCB (Y)

\begin{tabular}{|c|c|c|c|c|c|}
\hline \multicolumn{6}{|c|}{ Coefficientsa } \\
\hline \multirow{2}{*}{ Model } & \multicolumn{2}{|c|}{ Unstandardized Coefficients } & \multirow{2}{*}{$\mathbf{t}$} & \multirow{2}{*}{ Sig. } & \multirow{2}{*}{ Information } \\
\hline & B & Std. Error & & & \\
\hline (Constant) & 1,583 & 0.112 & 14,074 & 0.000 & \\
\hline Job satisfaction & 0.291 & 0.028 & 10,358 & 0.000 & Significant Positive Effect \\
\hline $\begin{array}{l}\text { Organizational } \\
\text { Commitment }\end{array}$ & 0.143 & 0.027 & 5,255 & 0.000 & Significant Positive Effect \\
\hline Leadership & 0.212 & 0.035 & 6,086 & 0.000 & Significant Positive Effect \\
\hline
\end{tabular}

a. Dependent Variable: OCB

Source: Results of analysis of SPSS 25.0

Interpretation and hypothesis testing $(\mathrm{H})$ in table 9 are as follows:

$$
\mathrm{Y}=1.583+0.291 \mathrm{X} 1+0.143 \mathrm{X} 2+0.212 \mathrm{X} 3+\mathrm{e} ;
$$

1. There is an effect of Job Satisfaction (X1) on OCB (Y) partially.

Based on table 9 above shows that the relationship between Job Satisfaction (X1) and OCB $(\mathrm{Y})$ is significant with $\mathrm{t}$-count of $10.358(\mathrm{t}$-count $>\mathrm{t}$ table $(\mathrm{df}=79)=1.99)$ and the value of Sig. $=0.000$. The coefficient value is positive, which is 0.291 , it indicates that the direction of the relationship between Job Satisfaction (X1) and OCB is positive at 29.1\%. Therefore, thehypothesis $1(\mathrm{H} 1)$ in this study which states that "Job Satisfaction (X1) has a significant effect on OCB (Y)" is accepted.

2. There is an effect of Organizational Commitment (X2) on OCB (Y) partially.

Based on table 9 above shows that the relationship between Organizational Commitment $(\mathrm{X} 2)$ and OCB $(\mathrm{Y})$ is significant with $\mathrm{t}$-count of $5.255(\mathrm{t}$-count $(\mathrm{df}=79)>1.99)$ and the value of Sig. $=0.000$. The coefficient value is positive, at score 0.143 which indicates that the direction of the relationship between Organizational Commitment (X2) and OCB is positive at $14.3 \%$. Therefore, the hypothesis $2(\mathrm{H} 2)$ in this study which states that "Organizational Commitment (X2) has a significant effect on $O C B(\mathrm{Y})$ ") is accepted.

3. There is an influence from Leadership (X3) on OCB (Y) partially.

Based on table 9 above shows that the relationship between leadership (X3) and OCB $(\mathrm{Y})$ is significant with $\mathrm{t}$-count of $6.086(\mathrm{t}$-count $(\mathrm{df}=79)>1.99$ and the value of Sig. $=0.000$. The coefficient value is positive, which is 0.212 , it indicates that the direction of the relationship between leadership (X3) and OCB is positive by $21.2 \%$. Therefore, the hypothesis 3 (H3) in this study which states that "Leadership (X3) has a significant effect on OCB (Y)" is accepted.

4. There is an effect of Job Satisfaction (X1), Organizational Commitment (X2), and Leadership (X3) on OCB (Y) simultaneously.

Based on the results of the simultaneous significance test (F test) in table 9 above shows the F-count value of 114.042 (F-count > F-table $(n=83$, and $k=3=2.72)$ and the Sig. $=0.000$, which indicates that the Job Satisfaction variable ( X1), the Organizational Commitment variable (X2), and the Leadership variable (X3) together have a significant effect on the OCB variable (Y). Therefore, the hypothesis $4(\mathrm{H} 4)$ in this study that states "Job Satisfaction, 
Organizational Commitment, and Leadership simultaneously has an effect on OCB" is accepted.

Table 10. Correlation Resultsof Inter-Dimensions

\begin{tabular}{|c|c|c|c|c|c|c|}
\hline \multicolumn{7}{|c|}{ Correlations } \\
\hline \multirow[b]{2}{*}{ Variable } & \multirow[b]{2}{*}{ Dimensions } & \multicolumn{5}{|c|}{ OCB (Y) } \\
\hline & & $\begin{array}{c}\text { Y.1 } \\
\text { Altruism }\end{array}$ & $\begin{array}{c}\text { Y.2 } \\
\begin{array}{c}\text { Conscientious- } \\
\text { ness }\end{array} \\
\end{array}$ & $\begin{array}{c}\text { Y.3 } \\
\text { Sportman- } \\
\text { ship } \\
\end{array}$ & $\begin{array}{c}\text { Y.4 } \\
\text { Courtesy }\end{array}$ & $\begin{array}{c}\text { Y.5 } \\
\text { Civic } \\
\text { Virtue } \\
\end{array}$ \\
\hline \multirow{6}{*}{$\begin{array}{l}\text { Job } \\
\text { Satisfaction } \\
(\mathrm{X} 1)\end{array}$} & X1.1 Supervision & 0.500 & 0.474 & 0.464 & 0.558 & 0.535 \\
\hline & X1.2 Colleagues & 0.371 & 0.394 & 0.446 & 0.428 & 0.595 \\
\hline & $\begin{array}{l}\text { X1.3 Working } \\
\text { Conditions }\end{array}$ & 0.367 & 0.436 & 0.412 & 0.468 & 0.510 \\
\hline & X1.4 Rewards & 0.518 & 0.419 & 0.426 & 0.470 & 0.479 \\
\hline & $\begin{array}{l}\text { X1.5 The Work } \\
\text { itself }\end{array}$ & 0.325 & 0.483 & 0.410 & 0.393 & 0.541 \\
\hline & X1.6 Promotion & 0.509 & 0.420 & 0.475 & 0.430 & 0.521 \\
\hline \multirow{3}{*}{$\begin{array}{l}\text { Organizational } \\
\text { Commitment } \\
\text { (X2) }\end{array}$} & $\begin{array}{l}\text { X2.1 Affective } \\
\text { Commitment }\end{array}$ & 0.159 & 0.306 & 0.459 & 0.336 & 0.294 \\
\hline & $\begin{array}{l}\mathrm{X} 2.2 \text { Commitment } \\
\text { to Continuity }\end{array}$ & 0.350 & 0.328 & 0.471 & 0.457 & 0.377 \\
\hline & $\begin{array}{l}\text { X2.3 Normative } \\
\text { Commitment }\end{array}$ & 0.419 & 0.368 & 0.569 & 0.503 & 0.432 \\
\hline \multirow{5}{*}{$\begin{array}{l}\text { Leadership } \\
\text { (X3) }\end{array}$} & $\begin{array}{l}\text { X3.1 Opennes to } \\
\text { Experience }\end{array}$ & 0.295 & 0.309 & 0.294 & 0.314 & 0.278 \\
\hline & $\begin{array}{l}\text { X3.2 } \\
\text { Conscientiousness }\end{array}$ & 0.501 & 0.262 & 0.245 & 0.552 & 0.296 \\
\hline & X3.3 Extraversion & 0.316 & 0.321 & 0.492 & 0.363 & 0.322 \\
\hline & $\begin{array}{l}\text { X3.4 } \\
\text { Agreeableness }\end{array}$ & 0.261 & 0.265 & 0.485 & 0.403 & 0.439 \\
\hline & X3.5 Neuroticism & 0.283 & 0.285 & 0.285 & 0.348 & 0.369 \\
\hline \multicolumn{2}{|r|}{$\mathrm{N}$} & 83 & 83 & 83 & 83 & 83 \\
\hline
\end{tabular}

\section{CONCLUSION AND SUGESTION}

Based on the research results, it can be concluded that; (1) there is an increase in job satisfaction of employees of BRI Yogyakarta Cik Ditiro branch office, due to the increase and influenceOCBso it is expected that the work and loyalty of BRI employees at the Yogyakarta Cik Ditiro branch office will increase and contribute positively to the company, (2) the increased commitment of BRI employees at the Yogyakarta Cik Ditiro branch office to keep a career in the company and feel guilty when leaving the company. This is because the positive influence on the application of the organizational commitment variable has a positive and significant effect on OCB. This means that the better the organizational commitment OCB will arise, (3) the current leadership provides direction and encourages employees to achieve company goals because of this positive and significant influenceOCB. This means that the better the leadership OCB will arise, and (4) job satisfaction, organizational commitment and leadership that is carried out comprehensively will increase employee's productivity so that the goals and targets of the company are achieved according to the vision that has been set. 
Based on the results of the analysis and the conclusions above, the suggestions that can be given to complement the results of this study are as follows:

1. The results of multiple linear regression analysis, and the correlation between dimensions show that job satisfaction, organizational commitment, and leadership significantly influence OCB, so it is necessary to do these suggestions;

a. the coworker dimension of the job satisfaction variable has the greatest influence and relationship to OCB, therefore coworker support, a pleasant and reliable coworker attitude increases employee job satisfaction which in turn will have a positive influence on employee's OCB.

b. normative commitment factors, especially from the comfort of employees at work and the workload felt by each employee, are expected to always be increased to improve employee's OCB.

2. The author suggest that further research may look forother variables that affect OCB. The high influence of job satisfaction on OCB found in this study opens the possibility of other influences from other variables, such as work discipline, work motivation, and competence.

\section{REFERENCE}

Allen and Meyer. (2013). The Measurement and Antecedents of Affective, Continuance and Normative Commitment to Organization. PT Elex Media Komputindo, Jakarta.

As'ad, M. (2004). Industrial psychology. Liberty: Yogyakarta

Avolio, BJ, Bass, BM, Jung, DI \&Berson, Y. (2003). Predicting unit performance by assessing transformational and transactional leadership.Journalof Applied Psychology, 88, 207-218. Available at www.apa.org/pubs/.../apl-882207.pdf.

Budiharjo, A. (2014). Organization - Towards Achievement of Optimum Performance in Improving Employee Performance. Second edition. Mitra Wacana Media, Jakarta., PrasetiyaMulya Publishing, Jakarta.

Darmawati, Hidayati, and Herlina. (2013). the influence of job satisfaction and organizational commitment on organizational citizenship behavior (OCB).Journal of Economia Vol 9 No 1.

Griffin. (2012).Leadership: Jakarta

Herminingsih. (2012). Spirituality and job satisfaction as factors for organizational citizenship behavior (OCB). Journal of Economic and Social Sciences, Volume 1, Number 2, p. 126-140.

Luthans., Fred. (2006). Organizational behavior. Tenth Edition, Publisher ANDI, Oemar, Yohanes. 2013

Organ, DW (2006). Organizational Citizenship Behavior: The Good Soldier Syndrome. Lexington, MA: Lexington Books.

Robbins et al. (2008) Organizational Behavior, Book 2, Edition 12. Jakarta: Four Salemba. 
Ristiana., Merry. (2013). The influence of organizational commitment and job satisfaction on organizational citizenship behavior (OCB) and employee performance in BhayangkaraTrijata Hospital Denpasar.Journal of Economics \&Management, Vol. 9, No. 1, pp, 56-70, January 2013.

Waspodo. (2012). The Influence of Job Satisfaction and Organizational Climate on Organizational Citizenship Behavior (OCB) of Employees at PT. Trubus Swadaya Depok. 